\title{
The excessive use of antioxidant therapy: A possible cause of male infertility?
}

\author{
Ralf Henkel, Inderpreet Singh Sandhu and Ashok Agarwal
}

\begin{abstract}
Reactive oxygen species and oxidative stress are closely associated with various pathologies such as neurodegenerative diseases, ageing and male infertility. Hence, antioxidants such as vitamin $\mathrm{C}$, vitamin $\mathrm{E}, \mathrm{N}$-acetyl cysteine, L-carnitine and folic acid are regularly used in various treatment regimens to protect cells from the damage induced by free radicals. However, given their over-the-counter availability at unnaturally high concentrations and also the fact that they are commonly added to various food products, patients may run a risk of consuming excessive dosages of these compounds, which may then be toxic. The few studies that have assessed antioxidant overuse and the associated adverse effects found that large doses of dietary antioxidant supplements have varying-if any-therapeutic effects even though free radicals clearly damage cells-a phenomenon that has been termed the "antioxidant paradox." Furthermore, overuse of antioxidants such as vitamin C, vitamin E, $\mathrm{N}$-acetyl cysteine may lead to reductive stress, which is reported to be as dangerous to cells as oxidative stress and can be the cause of diseases such as cancer or cardiomyopathy. Therefore, we feel that there is a need for more elaborate research to establish the clear benefits and risks involved in antioxidant therapy for male infertility.
\end{abstract}

\section{1 | Introduction}

Reactive oxygen species (ROS) are compounds of oxygen such as the superoxide anion $\left({ }^{\circ} \mathrm{O}_{2}{ }^{-}\right)$, hydrogen peroxide $\left(\mathrm{H}_{2} \mathrm{O}_{2}\right)$ and the hydroxyl $\left({ }^{\circ} \mathrm{OH}\right)$ radical containing free, unpaired electrons in their outer orbit, which makes them highly unstable and reactive (Greabu et al., 2008). ROS are physiologically generated in the mitochondria during aerobic metabolism, a process from which $1 \%-5 \%$ of the metabolised oxygen normally leaks out from the electron transfer chain and other cellular mechanisms (Boveris \& Chance, 1973; Halliwell, 2011; Hayyan, Hashim, \& Alnashef, 2016; Turrens, 2003) and are released as cytotoxic byproducts of cell metabolism (Raha \& Robinson, 2000). Due to their high reactivity, with half-life times in the nano-second range, ROS can damage various cellular structures such as proteins, lipid and nucleic acid resulting in protein and lipid peroxidation and DNA damage respectively (Halliwell \& Gutteridge, 1989). Reactive oxygen species have been associated with various pathologies such as ageing, neurodegenerative diseases, cancer and infertility (Agarwal, Saleh, \& Bedaiwy, 2003; Aitken, Clarkson, \& Fishel, 1989; Harman, 1956; Jones, Mann, \& Sherins, 1979; Li et al., 2013). Although ROS have significant detrimental 
effects on cellular mechanisms at higher concentrations, they are also necessary for various essential physiological functions such as cellular signalling, cellular growth, immune response against infections, embryogenesis, sperm maturation and capacitation (Dröge, 2002; Hampton, Kettle, \& Winterbourn, 1998; O'Flaherty, 2015). On the other hand, scavenging of superoxide by means of the action of superoxide dismutase (SOD) prevented capacitation-related tyrosine phosphorylation (O'Flaherty, Lamirande, \& Gagnon, 2005) in human spermatozoa, which essentially renders them unable to fertilise oocytes.

To counteract high levels of ROS, cells generally rely on various intrinsic and extrinsic antioxidant mechanisms. Endogenous antioxidants consist of enzymatic antioxidants such as SOD, catalase, thiol peroxidases and non-enzymatic antioxidants such as glutathione. In contrast, exogenous antioxidants consist of micronutrients such as vitamin A, vitamin $\mathrm{C}$, vitamin E, L-carnitine, $N$-acetyl cysteine as well as trace elements such as selenium and zinc (Halliwell \& Gutteridge, 1989), which have to be exogenously provided to the body in order to maintain a fine balance between oxidation and reduction (anti-oxidation) in any living cell (Valko et al., 2007).

Many people are living an unhealthy lifestyle leading to obesity, which causes a systemic inflammatory response, elevated production of adipokines, cytokines and high levels of ROS (Kahn \& Brannigan, 2017; Tsatsanis et al., 2015). In addition, exposure to toxicants including smoking, alcohol, radiation or environmental pollutants (Mathur, Huang, Kashou, Vaithinathan, \& Agarwal, 2011; Sharma, Biedenharn, Fedor, \& Agarwal, 2013) also results in oxidative stress. Clinically, physicians usually prescribe antioxidant supplements to treat oxidative stress-related disorders, including cases of male infertility. In addition, many patients take additional over-the-counter antioxidants because these compounds are regularly portrayed as promoters of good health as they are able to "combat" ageing and diseases. These supplements usually contain relatively high concentrations of few selected, purified antioxidants such as vitamin $\mathrm{C}$ and $\mathrm{E}$ and lycopene. Furthermore, many commonly available food products are already supplemented with vitamins and antioxidants. Consequently, it is possible for patients to inadvertently end up taking very high doses, or even too high doses of such antioxidants (Poljsak, Šuput, \& Milisav, 2013).

On the other hand, antioxidant supplementation has not shown consistent beneficial outcomes. Moreover, certain studies have even described the harmful effects of antioxidant intake. For instance, vitamin $\mathrm{E}$ at higher doses has been shown to increase all-cause mortality in patients (Miller et al., 2005). Further, it is well known that vitamin A supplementation does not have anti-cancer effects, but rather the opposite effect is seen in smokers (Alpha-Tocopherol, Beta Carotene Cancer Prevention Study Group, 1994). Low vitamin $\mathrm{C}$ intake is associated with elevated oxidative stress and DNA damage (Fraga et al., 1991). Nonetheless, administration of high ascorbate concentrations has also been shown to exert the same effects by causing oxidative stress (Aruoma, Halliwell, Gajewski, \& Dizdaroglu, 1991). Halliwell (2000) referred to this paradoxical effect of antioxidants as the "antioxidant paradox." 
Essentially, these contradictory effects highlight the fact that ROS generation and scavenging thereof by means of antioxidants is critical for normal bodily and cellular function, including that of male fertility. Thus, a fine balance between oxidation and reduction is essential to maintain this equilibrium (Figure 1) (de Lamirande \& Gagnon, 1995; Henkel, 2011; Kothari, Thompson, Agarwal, \& Plessis, 2010). Consequently, exposure to high levels of oxidants will cause a status of oxidative stress, which is well described and established as a major cause of male infertility (Agarwal, Makker, \& Sharma, 2008). In contrast, uncontrolled, unphysiologically high exposure to antioxidants (reductants) will also have significant negative effects on cells and male fertility; this might not be an exception. A shift of the bodily redox levels into a more reduced state is called "reductive stress." Reportedly, reductive stress is regarded as dangerous as oxidative stress (Castagne, Lefevre, Natero, Clarke, \& Bedker, 1999).

In other medical fields such as neuroscience or cardiology, this concept of reductive stress has already been embraced to explain specific diseases and pathologies. Despite signs being available, however, this has not been evaluated in Andrology so far. Therefore, this brief article will discuss the overall effects of antioxidants in male infertility and the possible risks involved that may lead to a state of reductive stress or oxidative stress through the "antioxidant paradox.".

\section{2 | Antioxidants and male infertility}

Since high levels of ROS are thought to cause various diseases including male infertility, the apparent logical solution to this condition is to assume that an increased antioxidant intake will not only help treat male infertility but also prevent it from occurring.

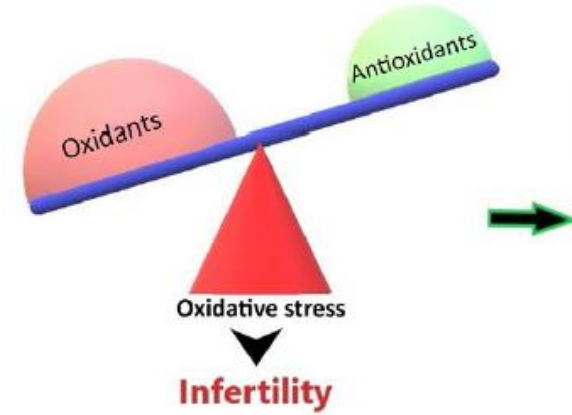

(a)

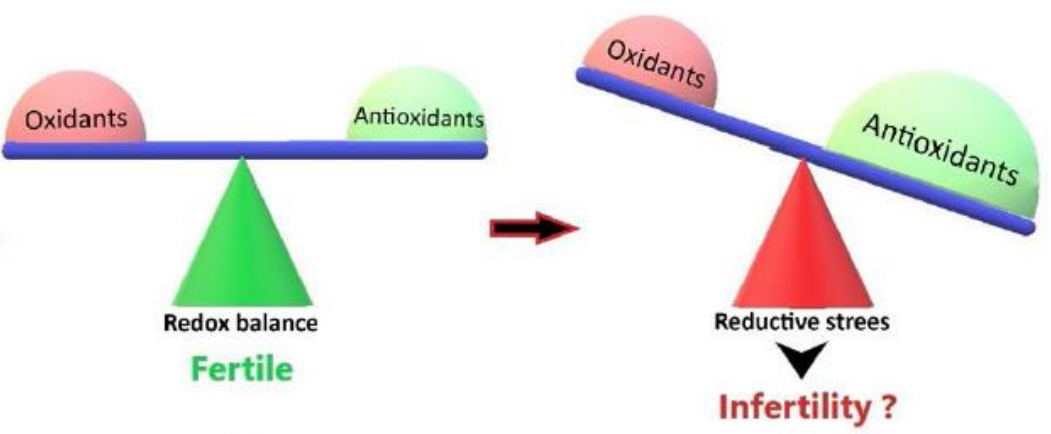

(b)

(c)

FIGURE 1 Redox balance; effects of oxidants and antioxidants. While among others, oxidative stress (a) is a cause of ageing, neurodegenerative diseases and infertility, reductive stress (c) can be a cause of cancer, cardiomyopathy, blood-brain-barrier dysfunction and infertility. Optimal physiological functions are carried out at balanced redox levels (b)

Antioxidants, in various formulations containing selected antioxidants at different concentrations, are readily available over-the-counter in the form of dietary supplements and are also commonly added to various food products and teas (Finley et al., 2011). In terms of male infertility, glutathione, vitamins $\mathrm{C}$ and $\mathrm{E}$, carnitine, $\mathrm{N}$-acetyl cysteine, co-enzyme-Q10, selenium and zinc are among the commonly used antioxidants as a treatment, although exact dosages and regimens have not been clearly defined (Agarwal \& 
Majzoub, 2016; Agarwal, Nallella, Allamaneni, \& Said, 2004). As a result, the studies conducted thus far were rather heterogeneous in both design and outcomes. Table 1 summarises the findings of studies that have assessed the effects of antioxidant supplementation on sperm parameters in clinically infertile men and resulted in positive effects with improved sperm parameters.

At the same time, various in vivo and randomised control trials have failed to show positive outcomes on semen parameters and some have even reported negative outcomes in terms of increased sperm DNA fragmentation or chromatin decondensation (Table 2). A meta-analysis by Showell et al. (2014) examined the low-quality evidence that was available at that point of time from only four small randomised, controlled trials and concluded that antioxidant treatment may increase pregnancy and live birth rates. In addition, antioxidant supplementation appeared not to increase the risk of miscarriage. Consequently, larger randomised, placebo-controlled studies are necessary in order to come up with recommendations that are more concrete. In one recent single-centre, randomised, double-blind, placebo-controlled trial including 104 subjects with and without varicocele, who were supplemented for 6 months with L-carnitine, acetyl-L-carnitine and other micronutrients, revealed that sperm concentration and motility improved significantly in both patient groups (Busetto et al., 2018). In another prospective, randomised study by Bozhedomov et al. (2017), the authors co-administered Land acetyl-L-carnitine, clomiphene citrate with vitamins and minerals to patients with idiopathic male infertility. Results show increased sperm concentration in patients with multiple sperm defects (oligoasthenoteratozoospermia). Contrary, progressive motility, normal sperm morphology and pregnancy rates, however, did not improve. 
TAB LE 1 Antioxidants and their use in treatment of male infertility

\begin{tabular}{|c|c|c|c|c|}
\hline Antioxidant & Mechanism of action & Natural sources & $\begin{array}{l}\text { Studies showing positive effects on } \\
\text { semen analysis }\end{array}$ & Improved parameters \\
\hline Vitamin C & $\begin{array}{l}\text { Neutralises hydroxyl } \\
\text { radical } \\
\text { Regenerates Vitamin E } \\
\text { and Glutathione }\end{array}$ & $\begin{array}{l}\text { Citrus fruits and vegetables } \\
\text { such as tomato, potato }\end{array}$ & $\begin{array}{l}\text { Akmal et al.( 2006) } \\
2000 \text { mg Vitamin C for } 2 \text { months in OS } \\
\text { men }\end{array}$ & $\begin{array}{l}\text { Mean sperm count } \\
\text { Sperm motility } \\
\text { Sperm morphology }\end{array}$ \\
\hline Vitamin $\mathrm{E}$ & $\begin{array}{l}\text { Neutralises lipid } \\
\text { peroxyl radical } \\
\text { Protects against lipid } \\
\text { peroxidation }\end{array}$ & $\begin{array}{l}\text { Nuts, olive oil Leafy } \\
\text { vegetables such as spinach }\end{array}$ & $\begin{array}{l}\text { Suleiman, Ali, Zaki, El-Malik, and Nasr } \\
\text { (1996) } \\
300 \mathrm{IU} / \text { day for } 6 \text { months in AS men }\end{array}$ & Sperm motility \\
\hline Carnitine & $\begin{array}{l}\text { Scavenges free } \\
\text { radicals } \\
\text { Prevent ROS } \\
\text { production }\end{array}$ & Meat and dairy products & $\begin{array}{l}\text { Lenzi et al. (2003) } \\
\text { L-carnitine } 2 \mathrm{~g} \text { /day for } 6 \text { months in OAT } \\
\text { men } \\
\text { Busetto et al. (2018) } 1,000 \mathrm{mg} \\
\text {-carnitine, } 500 \mathrm{mg} \text { acetyl-L-carnitine, } \\
725 \mathrm{mg} \text { fumarate, } 20 \mathrm{mg} \text { CoQ10, } \\
90 \mathrm{mg} \text { vitamin C, } 10 \mathrm{mg} \text { zinc, } 200 \mu \mathrm{g} \\
\text { folic acid, } 1.5 \mu \mathrm{g} \text { vitamin B12 for } \\
6 \text { months in OAT, with and without } \\
\text { varicocele }\end{array}$ & $\begin{array}{l}\text { Sperm concentration } \\
\text { Sperm motility }\end{array}$ \\
\hline $\begin{array}{l}\text { Co-enzyme } \\
\text { Q10 }\end{array}$ & $\begin{array}{l}\text { Scavenges free } \\
\text { radicals } \\
\text { Intermediate in ETC }\end{array}$ & Meat, whole grain and fish & $\begin{array}{l}\text { Nadjarzadeh et al. (2011) } \\
\text { CoQ10 } 200 \mathrm{mg} / \text { day for } 12 \text { weeks in } \\
\text { OAT men }\end{array}$ & $\begin{array}{l}\text { Increased TAC } \\
\text { Reduced LPO }\end{array}$ \\
\hline $\begin{array}{l}\text { N-Acetyl } \\
\text { cysteine }\end{array}$ & $\begin{array}{l}\text { Glutathione } \\
\text { resynthesis }\end{array}$ & $\begin{array}{l}\text { meat, eggs, broccoli, red } \\
\text { pepper }\end{array}$ & $\begin{array}{l}\text { Ciftci, Verit, Savas, Yeni, and Erel } \\
(2009) \\
\text { NAC } 600 \mathrm{mg} / \text { day in idiopathic infertile } \\
\text { men }\end{array}$ & $\begin{array}{l}\text { Sperm motility } \\
\text { Semen viscosity Semen } \\
\text { volume }\end{array}$ \\
\hline Zinc & $\begin{array}{l}\text { Decreased NF-кB } \\
\text { activation } \\
\text { Decreases ROS } \\
\text { production }\end{array}$ & Oysters, red meat, poultry & $\begin{array}{l}\text { Omu, Dashti, and Al-Othman (1998) } \\
\text { Zinc } 500 \text { mg/day for } 3 \text { months in AS } \\
\text { men }\end{array}$ & Sperm motility \\
\hline Selenium & $\begin{array}{l}\text { Antioxidant } \\
\text { selenoproteins }\end{array}$ & $\begin{array}{l}\text { Seafood, nuts, meat and dairy } \\
\text { products }\end{array}$ & $\begin{array}{l}\text { Safarinejad and Safarinejad ( } 2009 \text { ) } \\
\text { Selenium } 200 \mathrm{mg} \pm \text { NAC } 500 \text { mg/day } \\
\text { for } 26 \text { weeks in AS men }\end{array}$ & $\begin{array}{l}\text { Sperm motility } \\
\text { Sperm concentration }\end{array}$ \\
\hline Folic acid & $\begin{array}{l}\text { Scavenges free } \\
\text { radicals }\end{array}$ & $\begin{array}{l}\text { Leafy vegetables, nuts, beans, } \\
\text { dairy products, meats, eggs }\end{array}$ & $\begin{array}{l}\text { Wong et al. (2002) Folic acid } 5 \text { mg +Zinc } \\
66 \mathrm{mg} / \text { day for } 26 \text { weeks in subfertile } \\
\text { men }\end{array}$ & Sperm concentration \\
\hline
\end{tabular}

Note. AS, asthenozoospermia; CoQ10, co-enzyme Q10; ETC, electron transport chain; LPO, lipid peroxidation; NAC, N-acetyl cysteine; NF-kB, nuclear factor kappa B; OAT, oligoasthenoteratozoospermia; OS, oligozoospermia; ROS, reactive oxygen species; TAC, total antioxidant capacity. 
TAB LE 2 Antioxidant trials showing no improvement in semen parameters

\begin{tabular}{|c|c|c|c|}
\hline Study & Antioxidant regime & Study population & $\begin{array}{l}\text { Sperm parameters that showed no } \\
\text { improvement }\end{array}$ \\
\hline $\begin{array}{l}\text { Moilanen, Hovatta, and Lindroth } \\
\text { (1993) }\end{array}$ & Vitamin E 100 mg/day for 3 months & Unexplained infertility IUI & $\begin{array}{l}\text { Sperm concentration } \\
\text { Sperm motility } \\
\text { Sperm morphology }\end{array}$ \\
\hline Kessopoulou et al. (1995) & Vitamin E $600 \mathrm{mg} /$ day for 3 months & Infertility with high ROS & $\begin{array}{l}\text { Sperm concentration } \\
\text { Sperm motility } \\
\text { Sperm morphology }\end{array}$ \\
\hline $\begin{array}{l}\text { Rolf, Cooper, Yeung, and Nieschlag } \\
\text { (1999) }\end{array}$ & $\begin{array}{l}\text { Vitamin C } 1,000 \mathrm{mg}+\text { Vitamin } \mathrm{E} \\
800 \mathrm{mg} / \text { day for } 56 \text { days }\end{array}$ & Asthenozoospermia & $\begin{array}{l}\text { Sperm concentration } \\
\text { Sperm motility } \\
\text { Sperm morphology }\end{array}$ \\
\hline Greco et al. (2005) & $\begin{array}{l}\text { Vitamin } \mathrm{C} \text { and } \mathrm{E} 1 \mathrm{~g} / \text { day for } \\
2 \text { months }\end{array}$ & Idiopathic infertility & $\begin{array}{l}\text { Sperm concentration } \\
\text { Sperm motility } \\
\text { Sperm morphology }\end{array}$ \\
\hline Silver et al. (2005) & Various antioxidant formulations & Healthy volunteers & $\begin{array}{l}\text { Participants with moderate } \\
\beta \text { carotene intake had increased } \\
\text { sperm DNA fragmentation }\end{array}$ \\
\hline $\begin{array}{l}\text { Sigman, Glass, Campagnone, and } \\
\text { Pryor (2006) }\end{array}$ & $\begin{array}{l}\text { Carnitine } 1,000 \mathrm{mg} \text {, L-acetyl } \\
\text { carnitine } 500 \mathrm{mg} / \text { day for } 24 \text { weeks }\end{array}$ & Asthenozoospermia & Sperm motility \\
\hline Menezo et al. (2007) & $\begin{array}{l}\text { Vitamin } C+E(400 \mathrm{mg} \text { each), } \\
\beta \text { carotene }(18 \mathrm{mg}) \text {, zinc }(500 \mu \mathrm{mol}) \text {, } \\
\text { selenium }(1 \mu \mathrm{mol}) \text { per day for } \\
90 \text { days }\end{array}$ & At least 2 failed IVF/ICSI & $\begin{array}{l}\text { Increased chromatin } \\
\text { decondensation }\end{array}$ \\
\hline Hawkes, Alkan, and Wong (2009) & Selenium $300 \mathrm{mg} /$ day for 48 weeks & Normozoospermia & $\begin{array}{l}\text { Sperm motility } \\
\text { Sperm morphology }\end{array}$ \\
\hline
\end{tabular}

Note. IUI, intrauterine insemination; IVF, in vitro fertilisation; ICSI, intracytoplasmic sperm injection; ROS, reactive oxygen species.

Male and female reproductive systems protect spermatozoa from ROS-induced damage (Holt \& Fazeli, 2016) and also modulate sperm functions, for example, in terms of sperm storage in the female reproductive tract or gamete interaction (Agarwal, Gupta, \& Sharma, 2005; Holt \& Fazeli, 2016). In the rat, it was shown that changes in the antioxidant levels in the female reproductive tract may have significant implications on the fertilisation process itself (Behr et al., 2009). Moreover, higher antioxidant levels in follicular fluid in patients undergoing in vitro fertilisation (IVF) indicate that these patients may have better chances of becoming pregnant (Huang et al., 2014; Ozkaya \& Nazıroglu, 2010). On the other hand, an increased, unhealthy intake of high dosages of antioxidants may push the redox balance of the female organism into reductive stress with its negative consequences for the fertilisation process and embryo development. This may be the case in a reportedly healthy couple with recurrent pregnancy failures for 2 years after assisted reproduction (seven failed intracytoplasmic sperm injection (ICSI) cycles) with high levels of sperm DNA damage where both partners took high doses of antioxidants (husband: Royal jelly, Maca, Ashwagandha, Omega-3 fatty acids, vitamin C and D, Prelox and Spermimprove; wife: Olive leave extract, oregano oil, folic acid, DHEA, omega-3 fatty acids, royal jelly, vitamins B6 and D, co-enzyme Q10, multivitamin, Ultra Flora, L-lysine, and Moducare). According to the report of the wife, all these supplements were taken together. After discontinuing the antioxidant intake in both partners for 3 months, the wife became spontaneously pregnant (Henkel, unpublished observation). In this particular case, one can only speculate if high antioxidant levels led to male infertility or negatively affected implantation or early 
embryo development. However, this case illustrates the possible detrimental effects of high antioxidant activities in both male and female.

\section{3 | The antioxidant paradox and notable adverse effects}

The fact remains that on the one hand, ROS play an important role in the pathogenesis of several human diseases, but on the other hand, large doses of antioxidative supplements have produced conflicting results that have lead researchers to coin the term "antioxidant paradox" (Halliwell, 2000). This highlights the poor understanding of the exact mechanisms involved in administering antioxidant therapy. It appears that current antioxidant therapies to treat male infertility may be based on a misleading assumption that antioxidants in general are healthy, leading to the use of a wrong composition of the antioxidant treatment. In fact, specific negative effects have been reported for many of the usually recommended antioxidants such as selenium or vitamins C and E (Menezo et al., 2014). Taking selenium as an example, no deficiency has yet been described in the scientific literature. Furthermore, increased seminal plasma levels of selenium $(\geq 8 \mathrm{o} \mathrm{ng} / \mathrm{ml}$ ) were reported to be associated with decreased motility, asthenozoospermia and elevated abortion rates, whereas selenium levels between 40 and $70 \mathrm{ng} / \mathrm{ml}$ were reported to be optimal for reproductive performance (higher pregnancy rates and lower abortion rates) (Bleau, Lemarbre, Faucher, Roberts, \& Chapdelaine, 1984). In addition, there is increasing evidence that the antioxidant or pro-oxidant activities of antioxidants, even if they are deriving from natural sources, ultimately depend on their concentration (Bouayed \& Bohn, 2010). Moreover, since many of the antioxidant plant compounds act synergistically, antioxidant treatment will not only fail, but may even be toxic, if the relevant synergistic compound is absent. This could be seen in smokers supplemented with $20 \mathrm{mg} /$ day $\beta$-carotene (Alpha-Tocopherol, Beta Carotene Cancer Prevention Study Group, 1994) or $30 \mathrm{mg}$ $\beta$-carotene and 25,00o IU retinyl palmitate per day (Omenn et al., 1996) as this treatment significantly increased the risk of lung cancer in an efficacy trial against a placebo in 29,133 and 18,314 subjects respectively.

Additionally, various animal studies and clinical observations have indicated that high doses of antioxidants can produce adverse effects. These effects may be the result of imbalances in the physiological redox status either resulting oxidative stress through the phenomenon of the "antioxidant paradox" or in reductive stress (Wendel, 1987), which can be as detrimental to cells or the organism as oxidative stress, by causing cellular dysfunction (Castagne et al., 1999). Some of these adverse effects include cancer, cardiomyopathy, blood-brain barrier dysfunction, Alzheimer's disease or even embryogenesis defects (Fisher \& Mentor, 2017; Klein et al., 2011; Lloret, Fuchsberger, Giraldo, \& Vina, 2016; Rajasekaran et al., 2007; Ufer, Wang, Borchert, Heydeck, \& Kuhn, 2010; Wang \& Rogers, 2007).

In human reproduction, Ufer et al. (2010) stated that the cellular redox system has to be tightly controlled as the proper equilibrium between oxidation and reduction is fundamental for normal embryogenesis. Consequently, too high levels of antioxidants may induce teratogenic developments (Wang \& Rogers, 2007) leading to changes in the 
activity of redox-sensitive transcription factors and subsequently altered gene expression patterns (Harvey, Kind, \& Thompson, 2002). As a result, developmental retardation and malformations may occur. On the other hand, at implantation, the developing embryo is faced with an almost anoxic milieu (Leese, 1995), highlighting the narrow range of this redox balance for living cells.

Specifically in andrology, a study conducted by Menezo et al., 2007) assessed daily oral antioxidant treatment with vitamins $\mathrm{C}$ and $\mathrm{E}$ (400 $\mathrm{mg}$ each), $\beta$-carotene (18 mg), zinc (500 $\mu \mathrm{mol})$ and selenium $(1 \mu \mathrm{mol})$ in men whose female partners failed to become pregnant after IVF/ICSI. After therapy, sperm DNA damage decreased but sperm DNA decondensation increased, which can result in asynchronous chromosome condensation. DNA decondensation rates of more than $28 \%$ were shown to cause pregnancy failure in IVF and ICSI patients. The study concluded that increased DNA decondensation may be caused by the ability of vitamin $\mathrm{C}$ to break disulphide bonds in protamines in sperm DNA as this vitamin has the capacity to open the S-S-bonds of protamines (Donnelly, McClure, \& Lewis, 1999; Giustarini, Dalle-Donne, Colombo, Milzani, \& Rossi, 2008). Ultimately, reduction in the protamines will lead to nuclear decondensation problems and decreased fertility (Menezo et al., 2007). In an earlier in vitro analysis, positive and negative dose-related effects of vitamin $\mathrm{C}$ on sperm motility and sperm membrane lipid peroxidation have been observed. Vitamin $\mathrm{C}$ at concentrations below 1,000 $\mu \mathrm{M}$ resulted in increased sperm motility and decreased lipid peroxidation, while concentrations above $1,000 \mu \mathrm{M}$ have shown the complete opposite effect with complete sperm immobility at concentrations above 4,000 $\mu \mathrm{M}$ (Verma \& Kanwar, 1998). These studies show the paradoxical effects of antioxidants in the treatment of male infertility, which appear to be dose-dependent (Tables 1 and 2). However, one could also think that the composition of a specific antioxidant mixture, as it is given in various antioxidant supplements, will have an effect. Finally, in order to treat patients effectively, clinicians would have to know the actual individual redox level in each individual patient. The problem is that (a) no universally accepted method is available to test the bodily or seminal redox status of individuals; (b) one does not know what the normal redox level is; and (c) therefore, no generally accepted cut-off values are available. As a result, patients are not only taking antioxidants as they are made to believe that antioxidants are good for anti-ageing and the body in general, and furthermore treated by clinicians for male infertility because it is thought that oxidative stress is detrimental in particular.

Considering that our modern lifestyle with a lack of vitamin intake, exposure to environmental toxicants and/or smoking leaves the body rather in a state of oxidative stress. Consequently, treatment with antioxidants can help to alter this state. However, an unspecific and uncontrolled antioxidant intake might flood the body with antioxidants leading to reductive stress and causing infertility. Therefore, more efforts in investigating the redox status, its influence on the fertilisation process in general and sperm functional capacity specifically have to be undertaken. In the meantime, where no guidelines are available, clinicians should carefully examine and interview patients more thoroughly 
before they prescribe additional antioxidants in order to avoid the possibility of the patients overdosing on antioxidants causing reductive stress.

\section{4 | Conclusion}

The use of antioxidant therapy to treat OS-induced male infertility has been shown to have positive effects on semen parameters in some men, but not all. It is possible that in some studies, the role of OS as the cause of male infertility was overestimated as the patients' redox status was not accurately assessed before initiating the treatment. As a result, administration of exogenous antioxidants may instead either lead to oxidative stress induced by the "antioxidant paradox" or reductive stress with decreases in endogenous oxidants that are essential for the induction of physiological pathways resulting in an inhibition of these functions such as sperm capacitation. Hence, it emerges that antioxidants appear to have not only beneficial effects, but also significant adverse effects, if antioxidants are taken in excess or if synergistic compounds are lacking. Therefore, the consumption of antioxidants needs to be considered with caution and patients should be tested for their redox status before treating them with a specifically formulated supplement. Clearly, when treatment is indicated, it must be individualised to each patient once his normal redox status has been established. Further research is urgently needed to better define the benefits of antioxidant therapy, optimal doses and the possible risks involved.

\section{Conflict of interest}

Authors have no conflict of interest.

\section{Authors' contributions}

$\mathrm{RH}$ and AA had the idea for this review; RH together with ISS wrote the first draft of this manuscript; $\mathrm{RH}$ and AA critically reviewed the manuscript and added relevant information.

\section{ORCID}

Ralf Henkel http://orcid.org/0000-0003-1128-2982 Ashok Agarwal http://orcid.org/0000-0003-0585-1026 


\section{References}

Agarwal, A., Gupta, S., \& Sharma, R. (2005). Oxidative stress and its implications in female infertility-a clinician's perspective. Reproductive Biomedicine Online, 11, 641-650. https://doi.org/10.1016/ S1472-6483(10)61174-1

Agarwal, A., \& Majzoub, A. (2016). Role of antioxidants in male infertility. BJUI Knowledge, 1-9. https://doi.org/10.18591/BJUIK.0510.

Agarwal, A., Makker, K., \& Sharma, R. (2008). Clinical relevance of oxidative stress in male factor infertility: An update. American Journal of Reprodroductive Immunology, 59, 211.

Agarwal, A., Nallella, K. P., Allamaneni, S. S., \& Said, T. M. (2004). Role of antioxidants in treatment of male infertility: An overview of the literature. Reproductive Biomededicine Online, 8,616-627.https://doi. org/10.1016/S1472-6483(10)61641-o

Agarwal, A., Saleh, R., \& Bedaiwy, M. (2003). Role of reactive oxygen species in the pathophysiology of human reproduction. Fertility and Sterility, 79, 829-843. https://doi.org/10.1016/ So015-0282(02)04948-8

Aitken, R., Clarkson, J., \& Fishel, S. (1989). Generation of reactive oxygen species, lipid peroxidation, and human sperm function. Biology of Reproduction, 41, 183-197. https://doi.org/10.1095/ biolreprod41.1.183

Akmal, M., Qadri, J. Q., Al-Waili, N. S., Thangal, S., Haq, A., \& Saloom, K. Y. (2006). Improvement in human semen quality after oral supplementation of vitamin C. Journal of Medicinal Food, 9,440-442. https://doi.org/10.1089/jmf.2006.9.440

Alpha-Tocopherol, Beta Carotene Cancer Prevention Study Group. (1994). The effect of vitamin $\mathrm{E}$ and beta carotene on the incidence of lung cancer and other cancers in male smokers. New England Journal of Medicine, 330, 1029-1035.

Aruoma, O. I., Halliwell, B., Gajewski, E., \& Dizdaroglu, M. (1991). Copperion-dependent damage to the bases in DNA in the presence of hydrogen peroxide. Biochemical Journal, 273, 601-604. https://doi.org/10.1042/bj2730601

Behr, G. A., da Motta, L. L., de Oliveira, M. R., Oliveira, M. W., Gelain, D. P., \& Moreira, J. C. (2009). Modulation in reproductive tissue redox profile in sexually receptive female rats after short-term exposure to male chemical cues. Chemical Senses, 34, 317323. https://doi. org/10.1093/chemse/bjpoo4

Bleau, G., Lemarbre, J., Faucher, G., Roberts, K. D., \& Chapdelaine, A. (1984). Semen selenium and human fertility. Fertility and Sterility, 42, 890-894.

Bouayed, J., \& Bohn, T. (2010). Exogenous antioxidants-Double-edged swords in cellular redox state: Health beneficial effects at physiologic doses versus deleterious effects at high doses. Oxidative Medicine and Cellular Longevity, 3, 228-237. https://doi.org/10.4161/oxim.3.4.12858

Boveris, A., \& Chance, B. (1973). The mitochondrial generation of hydrogen peroxide. General properties and effect of hyperbaric oxygen. Biochemical Journal, 134, 707716. https://doi.org/10.1042/bj1340707

Bozhedomov, V. A., Lipatova, N. A., Bozhedomova, G. E., Rokhlikov, I. M., Shcherbakova, E. V., \& Komarina, R. A. (2017). Using L- and acetyl-L-carnintines in combination with clomiphene citrate and antioxidant complex for treating idiopathic male 
infertility: A prospective randomized trial. Urologïa, 3, 22-32. https://doi.org/10.18565/ urol.2017.3.22-32

Busetto, G. M., Agarwal, A., Virmani, A., Antonini, G., Ragonesi, G., DelGiudice, F., ... DeBerardinis, E. (2018). Effect of metabolic and antioxidant supplementation on sperm parameters in oligo-asthenoteratozoospermia, with and without varicocele: A double-blind placebo-controlled study. Andrologia, 5O(3), e12927. https://doi. org/10.1111/and.12927. [Epub ahead of print].

Castagne, V., Lefevre, K., Natero, R., Clarke, P. G., \& Bedker, D. A. (1999). An optimal redox status for the survival of axotomized ganglion cells in the developing retina. Neuroscience, 93, 313-320. https://doi. org/10.1016/So306-4522(99)00138-4

Ciftci, H., Verit, A., Savas, M., Yeni, E., \& Erel, O. (2009). Effects of N-acetylcysteine on semen parameters and oxidative/antioxidant status. Urology, 74, 73-76. https://doi.org/10.1016/j.urology.2009.02.034

de Lamirande, E., \& Gagnon, C. (1995). Impact of reactive oxygen species on spermatozoa: A balancing act between beneficial and detrimental effects. Human Reproduction, 1O(Suppl.1),15-21.https://doi. org/10.1093/humrep/10.suppl_1.15

Donnelly, E. T., McClure, N., \& Lewis, S. E. M. (1999). The effect of ascorbate and alpha-tocopherol supplementation in vitro on DNA integrity and hydrogen peroxide-induced DNA damage in human spermatozoa. Mutagenesis, 14, 505-512. https://doi.org/10.1093/ mutage/14.5.505

Dröge, W. (2002). Free radicals in the physiological control of cell function. Physiological Reviews, 82, 47-95. https://doi.org/10.1152/physrev.00018.2001

Finley, J. W., Kong, A. N., Hintze, K. J., Jeffrey, E. H., Ji, L. L., \& Lei, X. G. (2011). Antioxidants in foods: State of the science important to the food industry. Journal of Agricultural Food Chemistry, 59, 6837-6846. https://doi.org/10.1021/jf2013875

Fisher, D., \& Mentor, S. (2017). Antioxidant-induced reductive stress has untoward consequences on the brain microvasculature. Neural Regeneration Research, 12, 743-744. https://doi.org/10.4103/1673-5374.206640

Fraga, C. G., Motchnik, P. A., Shigenaga, M. K., Helbock, H. J., Jacob, R. A., \& Ames, B. N. (1991). Ascorbic acid protects against endogenous oxidative DNA damage in human sperm. Proceedings of the National Academy of Science, 88, 11003-11006. https://doi.org/10.1073/ pnas.88.24.11003

Giustarini, D., Dalle-Donne, I., Colombo, R., Milzani, A., \& Rossi, R. (2008). Is ascorbate able to reduce disulfide bridges? A cautionary note. Nitric Oxide, 19, 252-258. https://doi.org/10.1016/j.niox.2008.07.003

Greabu, M., Battino, M., Mohora, M., Olinescu, R., Totan, A., \& Didilescu, A. (2008). Oxygen, a paradoxical element? Romanian Journal of Internal Medicine, 46, 125135 .

Greco, E., Iacobelli, M., Rienzi, L., Ubaldi, F., Ferrero, S., \& Tesarik, J. (2005). Reduction of the incidence of sperm DNA fragmentation by oral antioxidant treatment. Journal of Andrology, 26, 349-353. https://doi.org/10.2164/jandrol.04146

Halliwell, B. (2000). The antioxidant paradox. Lancet, 355, 1179-1180. https://doi.org/10.1016/So140-6736(oo)02075-4 
Halliwell, B. (2011). Free radicals and antioxidants-quo vadis? Trends in Pharmacological Sciences, 32, 125-130. https://doi.org/10.1016/j. tips.2010.12.002

Halliwell, B., \& Gutteridge, J. M. C. (1989). Free radicals in biology and medicine, 2nd ed. Oxford, UK: Clarendon.

Hampton, M. B., Kettle, A. J., \& Winterbourn, C. C. (1998). Inside the neutrophil phagosome: Oxidants, myeloperoxidase, and bacterial killing. Blood, 92, 3007-3017.

Harman, D. (1956). Aging: A theory based on free radical and radiation chemistry. Gerontology, 11, 298-300. https://doi.org/10.1093/ geronj/11.3.298

Harvey, A. J., Kind, K. L., \& Thompson, J. G. (2002). REDOX regulation of early embryo development. Reproduction, 123, 479-486. https://doi. org/10.1530/rep.0.1230479

Hawkes, W. C., Alkan, Z., \& Wong, K. (2009). Selenium supplementation does not affect testicular selenium status or semen quality in North American men. Journal of Andrology, 30, 525-533. https://doi. org/10.2164/jandrol.108.006940

Hayyan, M., Hashim, M. A., \& Alnashef, I. M. (2016). Superoxide ion: Generation and chemical implications. Chemical Reviews, 116, 3029-3085. https://doi.org/10.1021/acs.chemrev.5boo407

Henkel, R. (2011). Leukocytes and oxidative stress: Dilemma for sperm function and male fertility. Asian Journal of Andrology, 13, 43-52. https://doi.org/10.1038/aja.2010.76

Holt, W. V., \& Fazeli, A. (2016). Sperm storage in the female reproductive tract. Annual Reviews in Animal Bioscience, 4, 291-310. https://doi. org/10.1146/annurev-animal-021815-111350

Huang, B., Li, Z., Ai, J., Zhu, L., Li, Y., Jin, L., \& Zhang, H. (2014). Antioxidant capacity of follicular fluid from patients undergoing in vitro fertilization. International Journal of Clinical Experimental Pathology, 7, 2273-2282.

Jones, R., Mann, T., \& Sherins, R. (1979). Peroxidative breakdown of phospholipids in human spermatozoa, spermicidal properties of fatty acid peroxides, and protective action of seminal plasma. Fertility and Sterility, 31, 531-537. https://doi.org/10.1016/ Soo15-0282(16)43999-3

Kahn, B. E., \& Brannigan, R. E. (2017). Obesity and male infertility. Current Opinions in Urology, 27, 441-445. https://doi.org/10.1097/ MOU.0ooooooooooo0417

Kessopoulou, E., Powers, H. J., Sharma, K. K., Pearson, M. J., Russell, J. M., Cooke, I. D., \& Barratt, C. L. R. (1995). A double-blind randomized placebo cross-overcontrolled trial using the antioxidant vitamin $\mathrm{E}$ to treat reactive oxygen species associated male infertility. Fertility and Sterility, 64, 825-831. https://doi.org/10.1016/ So015-0282(16)57861-3

Klein, E. A., Thompson, I. M. Jr, Tangen, C. M., Crowley, J. J., Lucia, M. S., Goodman, P. J., ... Baker, L. H. (2011). Vitamin E and the risk of prostate cancer: The Selenium and Vitamin E Cancer Prevention Trial (SELECT). JAMA, 306, 1549-1556. https://doi.org/10.1001/ jama.2011.1437

Kothari, S., Thompson, A., Agarwal, A., \& du Plessis, S. (2010). Free radicals: Their beneficial and detrimental effects on sperm function. Indian Journal of Experimental Biolology, $48,425-435$. 
Leese, H. J. (1995). Metabolic control during preimplantation mammalian development. Human Reproduction Update, 1, 63-72. https://doi. org/10.1093/humupd/1.1.63

Lenzi, A., Lombardo, F., Sgro, P., Salacone, P., Caponecchia, L., Dondero, F., \& Gandini, L. (2003). Use of carnitine therapy in selected cases of male factor infertility: A double-blind crossover trial. Fertility and Sterility, 79, 292-300. https://doi.org/10.1016/Soo15-0282(02)04679-4

Li, X., Fang, P., Mai, J., Choi, E. T., Wang, H., \& Yang, X. F. (2013). Targeting mitochondrial reactive oxygen species as novel therapy for inflammatory diseases and cancers. Journal of Hematological Oncology, 6, 19. https://doi.org/10.1186/1756-8722-6-19

Lloret, A., Fuchsberger, T., Giraldo, E., \& Vina, J. (2016). Reductive stress: A new concept in Alzheimer's disease. Current Alzheimer Research, 13, 206-211. https://doi.org/10.2174/1567205012666150921101430

Mathur, P. P., Huang, L., Kashou, A., Vaithinathan, S., \& Agarwal, A. (2011). Environmental toxicants and testicular apoptosis. Open Reproduction Science Journal, 3, 114-124. https://doi. org/10.2174/1874255601103010114

Menezo, Y., Entezami, F., Lichtblau, I., Belloc, S., Cohen, M., \& Dale, B. (2014). Oxidative stress and fertility: Incorrect assumptions and ineffective solutions? Zygote, 22, 8090.

Menezo, Y. J., Hazout, A., Panteix, G., Robert, F., Rollet, J., Cohen-Bacrie, P., ... Benkhalifa, M. (2007). Antioxidants to reduce sperm DNA fragmentation: An unexpected adverse effect. Reproductive Biomedicine Online, 14, 418-421. https://doi.org/10.1016/ S1472-6483(10)6o887-5

Miller, E. R., Pastor-Barriuso, R., Dalal, D., Riemersma, R. A., Appel, L. J., \& Guallar, E. (2005). Meta-analysis: High-dosage vitamin E supplementation may increase all-cause mortality. Annals of Internal Medicine, 142, 37-46. https://doi. org/10.7326/0003-4819-142-1-200501040-00110

Moilanen, J., Hovatta, O., \& Lindroth, L. (1993). Vitamin E levels in seminal plasma can be elevated by oral administration of vitamin $\mathrm{E}$ in infertile men. International Journal ofAndrology,16, 165-166.https:// doi.org/10.1111/j.1365-2605.1993.tbo1171.x

Nadjarzadeh, A., Sadeghi, M. R., Amirjannati, N., Vafa, M. R., Motevalian, S. A., Gohari, M. R., ... Shidfar, F. (2011). Coenzyme Q10 improves seminal oxidative defense but does not affect on semen parameters in idiopathic oligoasthenoteratozoospermia: A randomized double-blind, placebo controlled trial. Journal of Endocrinological Investigations, 34, e224-e228.

O'Flaherty, C. (2015). Redox regulation of mammalian sperm capacitation. Asian Journal of Andrology, 17, 583-590. https://doi.org/10.4103/1008-682X.153303

O'Flaherty, C., de Lamirande, E., \& Gagnon, C. (2005). Reactive oxygen species and protein kinases modulate the level of phospho-MEK-like proteins during human sperm capacitation. Biology of Reproduction, 73, 94-105.

Omenn, G. S., Goodman, G. E., Thornquist, M. D., Balmes, J., Cullen, M. R., Glass, A., ... Hammar, S. (1996). Risk factors for lung cancer and for intervention effects in CARET, the Beta-Carotene and Retinol Efficacy Trial.Journal of the National Cancer Institute, 88, 1550-1559. https://doi.org/10.1093/jnci/88.21.1550 
Omu, A. E., Dashti, H., \& Al-Othman, S. (1998). Treatment of asthenozoospermia with zinc sulphate: Andrological, immunological and obstetric outcome. European Journal of Obstetrics Gynecology and Reproductive Biology, 79, 179-184. https://doi.org/10.1016/So301-2115(97)00262-5

Ozkaya, M. O., \& Nazıroglu, M. (2010). Multivitamin and mineral supplementation modulates oxidative stress and antioxidant vitamin levels in serum and follicular fluid of women undergoing in vitro fertilization. Fertility and Sterility, 94, 24652466. https://doi.org/10.1016/j. fertnstert.2010.01.066

Poljsak, B., Šuput, D., \& Milisav, I. (2013). Achieving the balance between ROS and antioxidants: When to use the synthetic antioxidants. Oxidative Medicine and Cellular Longevity, 2013, 956792. https://doi. org/10.1155/2013/956792

Raha, S., \& Robinson, B. H. (2000). Mitochondria, oxygen free radicals, disease and ageing. Trends in Biochemical Science, 25, 502-508. https://doi.org/10.1016/So968-0004(00)01674-1

Rajasekaran, N. S., Connell, P., Christians, E. S., Yan, L. J., Taylor, R. P., Orosz, A., ... Benjamin, I. J. (2007). Dysregulation of glutathione homeostasis causes oxidoreductive stress and cardiomyopathy in R120GCryAB mice. Cell, 130, 427-439.

Rolf, C., Cooper, T. G., Yeung, C. H., \& Nieschlag, E. (1999). Antioxidant treatment of patients with asthenozoospermia or moderate oligoasthenozoospermia with high-dose vitamin C and vitamin E: A randomized, placebo-controlled, double-blind study. Human Reproduction, 14, 1028-1033. https://doi.org/10.1093/humrep/14.4.1028

Safarinejad, M. R., \& Safarinejad, S. (2009). Efficacy of selenium and/ or N-acetyl-cysteine for improving semen parameters in infertile men: A double-blind, placebo controlled, randomized study. Journal of Urology, 181, 741-751. https://doi.org/10.1016/j.juro.2008.10.015

Sharma, R., Biedenharn, K. R., Fedor, J. M., \& Agarwal, A. (2013). Lifestyle factors and reproductive health: Taking control of your fertility. Reproductive Biology and Endocrinology, 11, 66. https://doi. org/10.1186/1477-7827-11-66

Showell, M. G., Mackenzie-Proctor, R., Brown, J., Yazdani, A., Stankiewicz, M. T., Hart, R. J. (2014). Antioxidants for male subfertility. Cochrane Database Syst Rev 12:CDoo7411. https://doi.org/10.1002/14651858. CDoo7411.pub3. Epub 2014 Dec 15.

Sigman, M., Glass, S., Campagnone, J., \& Pryor, J. L. (2006). Carnitine for the treatment of idiopathic asthenospermia: A randomized, double-blind, placebo-controlled trial. Fertility and Sterility, $1409-1414$. https://doi.org/10.1016/j.fertnstert.2005.10.055

Silver, E. W., Eskenazi, B., Evenson, D. P., Block, G., Young, S., \& Wyrobek, A. J. (2005). Effect of antioxidant intake on sperm chromatin stability in healthy nonsmoking men. Journal of Andrology, 26, 550-556. https://doi.org/10.2164/jandrol.04165

Suleiman, S. A., Ali, M. E., Zaki, Z. M., El-Malik, E. M., \& Nasr, M. A. (1996). Lipid peroxidation and human sperm motility: Protective role of vitamin E. Journal of Andrology, 17, $530-537$.

Tsatsanis, C., Dermitzaki, E., Avgoustinaki, P., Malliaraki, N., Mytaras, V., \& Margioris, A. $\mathrm{N}$. (2015). The impact of adipose tissue-derived factors on the 
hypothalamic-pituitary-gonadal (HPG) axis. Hormones (Athens), 14, 549-562. https://doi.org/10.14310/horm.2002.1649

Turrens, J. F. (2003). Mitochondrial formation of reactive oxygen species. Journal of Physiology, 552, 335-344. https://doi.org/10.1113/ jphysiol.2003.049478

Ufer, C., Wang, C. C., Borchert, A., Heydeck, D., \& Kuhn, H. (2010). Redox control in mammalian embryo development. Antioxidants and Redox Signaling, 13, 833-875. https://doi.org/10.1089/ars.2009.3044

Valko, M., Leibfritz, D., Moncol, J., Cronin, M. T., Mazur, M., \& Telser, J. (2007). Free radicals and antioxidants in normal physiological functions and human disease. International Journal of Biochemistry and Cell Biology, 39, 44-84. https://doi.org/10.1016/j.biocel.2006.07.001

Verma, A., \& Kanwar, K. C. (1998). Human sperm motility and lipid peroxidation in different ascorbic acid concentrations: An in vitro analysis. Andrologia, 3o, 325-329. https://doi.org/10.1111/j.1439-0272.1998. tbo1178.x

Wang, C. C., \& Rogers, M. S. (2007). Oxidative stress and fetal hypoxia. In G. Laszlo (Ed.), Reactive oxygen species and disease (pp. 257-282). India: Research Signpost.

Wendel, A. (1987). Measurement of in vivo lipid peroxidation and toxicological significance. Free Radical Biology in Medicine, 3, 355-358. https://doi.org/10.1016/So891-5849(87)80047-3

Wong, W. Y., Merkus, H. M. W. M., Thomas, C. M. G., Menkveld, R., Zielhuis, G. A., \& Steegers-Theunissen, R. P. M. (2002). Effects of folic acid and zinc sulfate on male factor subfertility: A double-blind, randomized, placebo controlled trial. Fertility and Sterility, 77, 491-498. https://doi.org/10.1016/So015-0282(01)03229-0 